\title{
THE ANCIENT ECONOMY, MODERNITY AND THE EAST AND WEST RELATIONSHIP: THE CONTRIBUTIONS OF KARL MARX AND MAX WEBER
}

\author{
Alexandre Galvão Carvalho ${ }^{1}$
}

\begin{abstract}
The work of Karl Marx (1818-1883) and Max Weber (1864-1920) on the economy and society of the ancient world inaugurate a new perspective in relation to the economists of the 18th and 19th centuries and in debates about the old economy locked in Germany in the late 19th century. Different from neoclassical economists and the modernists and primitivism, these authors will defend the thesis of a radical break between the old world and the modern. A discontinuity marked, for Marx, the birth of the capitalist system, and for Weber, of modern capitalism. In addition to this similarity, these thinkers have reinforced the Eurocentric view by stating that the cultural and political roots of modern west lie in Classical Antiquity, reinforcing a tradition of thought of deep rifts between the ancient societies of the East and the societies of the Greco-Roman world, much contested in current historiography.
\end{abstract}

Keywords

Karl Marx; Max Weber; Ancient Economy.

\footnotetext{
${ }^{1}$ Assistant Professor, State university of Sowthwest Bahia, Vitória da Conquista, Brazil. E-mail: galvaocarvalho@uol.com.br
} 


\section{Resumo}

Os trabalhos de Karl Marx (1818-1883) e Max Weber (1864-1920) sobre a economia e sociedade do mundo antigo inauguram uma nova perspectiva em relação aos economistas dos séculos XVIII e XIX e nos debates acerca da economia antiga travados na Alemanha no final do século XIX. Diferente dos economistas neoclássicos e dos modernistas e primitivistas, esses autores irão defender a tese de uma ruptura radical entre o mundo antigo e o moderno. Uma descontinuidade marcada, para Marx, pelo nascimento do sistema capitalista, e para Weber, do capitalismo moderno. Além dessa similaridade, esses pensadores reforçaram a visão eurocêntrica ao afirmarem que as raízes culturais e políticas do Ocidente moderno repousam na Antiguidade Clássica, reforçando uma tradição de pensamento de profundas clivagens entre as sociedades antigas do Oriente e as sociedades do mundo greco-romano, muito contestada na historiografia atual.

\section{Palavras-chave}

Karl Marx; Max Weber; Economia Antiga. 


\section{Introduction}

For the neoclassical economists as Adam Smith, Malthus and Steuart, the comparative approach of economic analysis, with examples and classical texts, is marked by an absence of any fundamental concept that distinguishes the modern world in its economic constitution or superior one in its qualities. Their explanations, permeated with historical material used to emphasize general economic principles and the variability of human behavior, generally assume a continuity and comparability between the past and the present. The distinctions were characterized in terms of stages of economic development in history, pastoral for agriculture and then for the trade.

In the nineteenth century, the theoreticians of political economy, as David Ricardo, are more concerned with identifying economic laws and structures based on logical principles, rather than producing them from empirical evidence. A more abstract and deductive discipline, concentrated on purely economic matters, in which the history, along with the Classical Antiquity, was only used to show the superiority of the economic knowledge. Thus, the Classical Antiquity had little to offer the modern economic thought, with few examples worthy of being mentioned, as Aristotle, a pioneer of economic analysis "rudimentary".

The contempt for Antiquity is explained by the identification of which the principles and the laws that determine the operations of the economy were universally applicable and identifiable in any past historical context. The historical analysis would add nothing to the attempts to understand the economy, and can even create confusion by causing gaps and suggesting that the logically derived economic principles could be rejected in favor of the contingent circumstances. Therefore, the modernity did not need to be analyzed or defined since the principles of political economy were universal. ${ }^{2}$

The German economists of the nineteenth century rejected this ahistorical approach of classical political economy. The preference for historical methods for the intend of historicizing classical political economy was the more general purpose of German thinkers as Adam Müller, Friedrich List and F. K. Savigny. Theirs works influenced the members of the Historic School of Economic Theory that dates to the 1840s, whose first representatives were Wilhelm Roscher, Bruno Hildebrand and Karl Knies and, subsequently, Gustav von Schmoller, in the 1870s. Roscher argued

\footnotetext{
2 For a more detailed discussion of the role of the classic economists in relation to antiquity, see MORLEY, N. The Great Transformation: Ancient and Modern Economics. In: Antiquity and Modernity. Oxford: Wiley-Blackwell, 2009.
} 
for a comparative study of all peoples to discern the similar traces that could constitute in a law of development. For these authors, in the evolutionist perspective, and one next to Adam Smith, the pre-modern societies had already reached higher levels of development. Roscher and List characterized the Greek classical cities and, especially the Roman Empire in terms much more positive, with parallels between the past and the present, as well as contrasts.

These ideas found expression in the work of economic historians, such as Karl Bücher and historians of Antiquity, as Theodor Mommsen. However, among these authors, the convergence was only in relation to the importance of economic factors in the analysis of the ancient world and history as an element to be taken into account by the political economy, since Mommsen (1854: 368) had identified economic factors in the fall of the Republic, as a result of unilateral prominence of capital in the Roman economy, inseparable from the evils of a capitalist system that could not fail to appear, while Karl Bücher argued, in his essay Die Entstehung der Volkswirtschaft (The Rise of the National Economy), the discovery of specific laws for pre-capitalists societies, in a evolutionist perspective, in contrast to the classical political economy that uses categories of modern national economy in every age, based on the exchange of goods, absent in pre-capitalists societies. Thus, for this author, unlike many historians of the age, the ancient world was shaped by the closed household economy, without exchanges, because the production is personal, and the goods are consumed at the same place where they are produced.

The perspective of Bücher that all the ancient world was dominated by oikos, without exchanges, generated a strong controversy with historians in Germany, as, for example, Eduard Meyer, who disputed Bücher, claiming that the ancient world had a completely developed economy both in the industrial plan as capitalist one, with exchanges and trade. The differences were much more of degree than of nature. The discussions between Bücher and Meyer originated the famous debate of the oikos, from the end of the nineteenth century between primitivism, followers of Bücher and modernists, close to the opinion of Meyer. Despite these differences, both Bücher and Meyer, and his successors, defended the existence of a single continuity between the ancient world and the modern one. For the primitivists, a linear continuity, for the modernists, cyclical one. 


\section{The Discontinuity between the Ancient and Modern World and the Importance of Economic Sphere}

Max Weber (1864-1920) began his academic career developing works of Ancient History. Mommsen considered him as his successor and Weber's first work on the ancient world, Die römische Agrargeschichte (Roman Agrarian History), from 1891, was very well received by historians. At the same time, he is considered by many as the more distinguished heir from the Historic School of Economic Theory, having occupied the chair of political economy at Heidelberg, in place of Karl Knies. Despite the influences of Mommsen and the Historic School of Economic Theory, rather the importance of history to the understanding of the economic development of societies, Weber broke with the idea that, between the ancient and modern world, it should not emphasize the discontinuities. For him, the question of the differences between the pre-modern and modern societies was central in their theoretical framework about the nature and origins of capitalism, a central element of their research.

It is in the work of Karl Marx (1818-1883) on which the greater impact of this change of perspective rests, carried out by Weber, in relation to economists and historians, because the changes of the modern world, with resonances in all aspects of human life, were the major transformation to Marx, a dramatic discontinuity in the historical development that separates the modern period from the ancient one, being the economic sphere in the center of his arguments about the interpretations of the nature and development of modernity. This common perspective is very different from the writings of thinkers of the eighteenth and nineteenth centuries and Germans economists and historians of the nineteenth century, being Weber debtor of Marx by this break, having both taken capitalism as a central element of their research.

However, if there is convergence on the rupture, the discontinuity between the ancient and modern world, the forms of explanation of this rupture are divergent. If the failure of antiquity in achieving the modern capitalism is a common element in Marx' and Weber's analyzes; on the other hand, the arguments used by them are distinct.

Marx defines a qualitative disruption between the pre-capitalist world and the modern world, capitalist one. The continuous revolution in the production process, the obsession with productivity increase and the exploitation of science for this purpose are characteristics of capitalism. Weber defines capitalism in a different way of Marx, not limiting it to the modern world, however he differently characterizes it in antiquity. 
In the Grundrisse der Kritik der politischen Ökonomie (Foundations of the Critique of Political Economy), written between October 1857 and May 1858, but only published in 1939 and 1941, in Moscow, Marx, in the "Introduction", in defining his object, the material production, different from Adam Smith and Ricardo, says that his concern is the socially determined individual production. In his model of relations of production of pre-capitalist formations, in "The Chapter on Capital" of the Grundrisse, within the item entitled 'Forms which precede capitalist production (Concerning the process which precedes the formation of the capital relation or of original accumulation)', Marx assumes that precapitalist societies differ from capitalist societies, because in pre-capitalist societies the individual himself relates to the objective conditions of his labor as his ownership, setting up the natural unity of labor with its objective prerequisites. This unity is seen by Marx as a spontaneous relationship - natural - and its dissolution, which is only completed in capitalism, is a historic process, in which there is a transformation in the relations of individual with the community, an individualization, being the exchange one of the agents of this individualization. In his analysis of the pre-capitalist societies Marx seeks to establish the conditions necessary for the emergence of capital as a decisive social relation, rather in a mode of production. Marx did not seek the inexorable causes and effects to rebuild a linear history in the past, like Bücher, but retroactively to understand the processes of social change, allowing that the present arose as it displays (Turatti, 2011: 80).

The existence of a free labor, transformed into a good to be exchanged for money to reproduce itself, is a fundamental historical prerequisite of capitalist society. To happen, it is necessary that it has dissolved a whole range of economic forms in which the laborer was not separated from the objective conditions of production. These conditions of non-separation are in all the economic pre-capitalist formations. This is a key feature of the separation between pre-capitalist and capitalist societies.

Therefore, according to Marx, a unified economy around the capital was not possible to be found in the ancient world, because the pre-capitalist world was characterized by extremely diverse and local parallel, multiple, limited developments. Despite the capital holding moments of unification, as in the economies of the classic peoples these appeared as separate entities from the rest of the communities, since they lived in the pores, interstices in the ancient world. The agrarian economy of classic peoples and mercantile one of trade peoples, Phoenicians and Carthaginians, appeared in juxtaposition, separate and not as parts of the same integrated economy. Even Limited, the process of circulation of 
goods and the emergence of exchange value can modify the production with a disruptive action, but in classical antiquity it occurs without arriving to cause the overthrow of predominate economic relations. In Greco-Roman societies, but not in Asian one, although the process of exchange was separated from production, it has partial effects on production itself, giving rise to the partial conjunction between exchange value and use value, since this appears at the beginning and end of the process: money is a mediator of the exchange of products. Thus, the commercial capital appears as a mediator between extremes that it does not dominate and between prerequisite which do not create (Cardoso, 2011: 33-36).

Marx takes as example the antiquity to show that the modern world is transitory and surpassable, because the superiority that the modernity spreads in relation to the ancient world is a lie, since it failed to achieve its promises, for example, the overcoming of hunger, ignorance, and shortage. Overcoming in scale has not meant to overcome the antiquity in duration. To take the material basis for the analysis of all the societies and seek to identify the laws of economic development on a historical scale, Marx has sought to highlight the inadequacy of capitalism and its illegitimate assumption of universality and timelessness, by means of the different modes of production. Organized around various principles of capitalism with differences in values and economic mentality, the ancient world had the central element of its distinction from the modern world in the mode of labor organization. The exploitation of the free labor for owners of capital was radically different from the slave logic, which was dominant in the ancient world (Morley, 2009: 41-43). Slavery was incompatible with capitalism, except as an anomaly. On the other hand, the free labor had little or no influence in the ancient economy. Therefore, it makes no sense to speak of capitalism or capitalists in the ancient world.

The phenomenon of capitalism has been at the center of the concerns of economic sociology of Max Weber, being the uniqueness of the modern West, his more central question, but unlike Marx, his scheme of socioeconomic comparative structures does not preclude the possibility of forms of capitalism prior to the bourgeois form that emerged after the Renaissance. The diversity of the causes and the different trends, typical of orientation of the acquisitive activities that did not cease to intervene during its historical development, are the arguments that led him to believe that there was not one capitalism, but there were capitalisms, hence it is not possible to reduce it to a formula. The capitalism is present when "the industrial provision for the needs of a human group is 
carried out by the method of enterprise, irrespective of what need is involved" (Weber apud Freund, 1980: 127). These fundamental elements allowed Weber to assert that there were embryos or forms of capitalism: sometimes adventurer one, sometimes market one, oriented toward the war, for the policy or for the administration, in China, India, Babylon, Classical Antiquity and the Middle Ages. However, if other fundamental elements are added to those features, for example, rational capitalistic establishment, that is, based on the calculation of capital, associated with forecasts of a regular market and the capitalist organization of (formally) free labor, as well as a distribution of services purely oriented by the principles of economy of exchange, then we are facing a capitalism: the west modern capitalism. In other words, the whole capitalist society presents oddities that we did not find in other societies of the same type. Hence the importance of the distinction of Weber between the modern world, dominated by rational capitalism and market capitalism - rational and centered on the formally peaceful opportunities from the market; and the ancient world, with characteristics of politically oriented capitalism, defined as the exploitation of profit opportunities that arise from the exercise of political power, not being totally absent some aspects of market capitalism, but not dominant.

In his first work on economic history of antiquity, Die römische Agrargeschichte (Roman Agrarian History), Weber sparsely studied his concept of political capitalism and its differences with the modern world. This work, much closer to the Modernists, written in a time when Weber was closely associated with the Mommsen, shows us that he had taken over the conventional understanding concerning the nature of modern capitalism and anachronistically designed their forms in the past to the conditions of the ancient society. Weber is interested in discovering precisely how ancient legal institutions came to recognize a concept of ownership remarkably close to ours, private property, that can only be achieved with the full development of the Roman imperialism and the economic opportunities that were opened with the massive expansion of the so-called ager publicus. The landed property in general was treated as an object of economic interest and, in the view of Weber, as a capitalist emerging stratum. The full effect of all this was to allow a kind of agrarian capitalism of enormous extent in which capitalist interests quickly came to dominate the economic life and social affairs in general. Weber is more concerned in describing and analyzing the specifically agrarian dimensions this first form of capitalism, in which the Roman patriciates were capitalist in an adequate sense of the term. He also speaks of "capitalist methods", "a capitalist ethos", and even occasionally, "a capitalist economy" (Love, 1991: 14-16). Despite the disagreement with 
the perspective of Marx, who does not see capitalism in the ancient world and, therefore, the impossibility of development of capital, Sergio da Mata (2013) sees in this work a debt of Weber with analysis of Marx on the primitive accumulation of capital in England, in which Weber tried to anticipate the general trends of the process in Germany and propose public policies to face the problem.

In this work, if the influence of Monnsem is predominant, there is no doubt that in his famous paper "Die Sozialen gründe des Untergangs der antiken Kultur" "The Social Causes of the Decline of the Ancient Civilizations), published in 1896, Weber breaks with the perspective of that work and presents an analysis that is considered by many as the text of greater influence of Marx, ${ }^{3}$ as well as he demonstrates sympathy for primitivism, but does not share the opinion that the oikos dominated all the Antiquity. At the beginning of the text, he asserts that "there is little or nothing which ancient history can teach us about our own social problems" (Weber, 2013: 391). The decline of the ancient culture only had one historical interest. Therefore, the characteristics of the social structure of Antiquity should become clear.

Weber said that the ancient culture was essentially urban. The ancient town exchanged products of urban industry with the fruits of the close surrounding agricultural edge. A direct exchange between producers and consumers, no need for imports from outside. The international trade does not affect the autarchic ideal of the ancient city, for it was reduced to expensive articles - the luxury objects - with high cost of transport and, was only concerned to a small stratum consisting of owners. In the face of such a picture, Weber (2013: 392) states: "Such trade cannot be compared in any way with modern commerce." Here is a persuasive counterpoint to the modernist perspective.

In this essay, Weber attaches casual decisive importance to the economic infrastructure. About the economic impact of slavery, Weber makes a more creative load of opposition base/superstructure of Marx. He defines

\footnotetext{
${ }^{3}$ In a review of the book The Agrarian Sociology of Ancient Civilizations, Jonathan M. Wiener finds several points in common between the text "Die Sozialen gründe des Untergangs der antiken Kultur" ("The Social Causes of the Decline of the Ancient Civilization") and the analysis of Marx, as for example, the distinction of quantitative expansion and qualitative transformation of production for the market. The author asserts that Weber's analysis is notable because it lacks everything that we consider 'Weberian' characteristic traces. In The Agrarian Sociology of Ancient Civilizations, the author argues that Weber uses the Marxist method take as a starting point for the analysis of a social formation the mode in which the ruling class extracts the work surplus arising out of the class dominated (Wiener, 1982: 389-401).
} 
the ancient civilization as slavery, characterized by a progressive accumulation of men, purchased at a low price, derived from the incessant nature of wars of Antiquity. This prevented the technical progress of the ancient civilization and concentrated in the hands of the owners of slaves to produce a surplus, produced by slave labor for sale on the market, in addition to the domestic production for the needs of the own oikos. Here is how Weber understood the 'contradiction of the ancient economy: motivated by the needs of the upper classes the growth of the number of slaves and the increasing scale of production for the market discouraged the development of local domain of the urban economy based on the production of orders for customers and the local trade, as it was in the Middle Ages. At the time that the wars of conquest have ceased and, consequently, the flow of slave labor has too, the system collapsed, because the city market, fostered by the slave production and not by the free labor, has lost its link with the large properties and there is no more the exchange of foodstuff and labor with the surrounding countryside. The result was the growth of natural economy, with the slave as a vassal within the independent family, outside of the oikos, allowing the lord to keep his provision of labor force, without the need for conservation of slave labor. A transformation in the lowest classes of society; "they once again had a right to family life and private property". (Weber, 2013: 400). Thus, the fall of the Roman Empire is the political consequence of the gradual disappearance of trade, and therefore, the expansion of natural economy. It was the end of a political superstructure of a regime of monetarized economics, for it was no longer adapted to the economic infrastructure that dominated in a regime of natural economy.

It is difficult to avoid the conclusion that, in this essay, the mode of Weber's explanation is almost indistinguishable from the so-called historical materialism. From the above exegesis, Weber places a huge importance on a single material factor: i.e., an adequate supply of cheap slaves as the basis of ancient civilization. All other elements of the description - the growing ineffectiveness of the army, the bureaucratization of the later imperial state, the change of cultural life of cities to the countryside - seem to gain their specific gravity of its connection with the factor of slavery. But, despite its superficial resemblance to economic determinism, Weber utilizes perspectives which in effect go beyond a monocausal approach, because he provides a quite different model of the socio-economic base of ancient society than that of Marx. In fact, He analyses a wide range of phenomena, such as the military and political preconditions of slavery, the structure of urban life, the struggles of rich and poor over landownership, the nature of the oikos 
and the forms of the family, the formation of a market sector at the intersection of the urban and rural spheres, luxury-based international trade, and other features In the essay of Weber, despite its reductionist trends, it is realized the rich and varied range of ideal types - urban economy, economy of oikos, economy in the medieval city, feudal army, city-state, the coastal trading city, plantation economy, natural economy and so on - and the causal relations, transitions and mixes. Thus, it displays a practice belies his meta-historical claim to have demonstrated the "economic" cause of the collapse of ancient civilization, because his explanations involve various social and political data (Love, 1991: 22-25).

The discontinuity between the ancient world and the modern one, existing in the analysis of Marx and Weber, has distanced itself not only of the economists of the eighteenth and nineteenth centuries, but also from the explanations of the modernists and primitivists, because among them there were a convergence concerning the genealogical origin between the end of the ancient world and the modern world, it is more emphasized among the modernists, who reduces the distance between the two worlds to merely a chronological freak, but it is not absent among the primitivists, although mitigated by a greater emphasis on the differences arising from the slow progress accumulated over a millennium.

In fact, this discontinuity is probably one of the greatest contributions of these two thinkers to the studies of Ancient History, with repercussions in current historiography. Aldo Schiavone, for example, reasserts the inseparability between the Roman economy and the European and Atlantic modern one, existing in both wholly distinct worlds, separated qualitatively different, characterized by strata of mentality, habits, behaviors, material and cultural conditions, from whose formative lines differ dramatically (Schiavone, 2005: 246).

Schiavone not only reasserts this discontinuity, but also seeks to explain his motives and reasons, leaving us with a feeling that the analyzes of Marx and Weber are complementary and open a base of abundant research for Social History. To take as a hypothesis that there was no continuity between the end of the Roman Empire and the modern world, Schiavone raises two fundamental issues that were present in Marx's and Weber's reflections: the slave character and the technological obstacles in the ancient classic world as differentiator elements of these two worlds. The author explores these themes on the assumption that the Greco-Roman world was characterized by the following tripod: the spread of slavery-commodity, the devaluation of labor and manufacturing materiality and the constant mechanical deficit in 
production processes. The revulsion of labor in that society can be traced back to the individualistic mentality that it was stated in the aristocracies and Greek and Roman city-states. In this world, what was stressed was not the materiality of action, of production, but the fostering of nature and civil and political freedom. The small landed property and its direct exploration were the political status of citizenship. This economic form embodied in a political institution, the city-state, formed the cultural and mental framework of the Greco-Roman world. Concomitantly, the social organization influenced the forms and modes of thinking the transformed artificiality, that is, the attitude of that society in relation to the nature and its phenomena. There was a chasm between knowledge and transformation of nature. The ancient world was not able to overcome the mental barriers of metaphysics to recognize the tangible world as a territory of reason, controlled by the experimental verification. There was no connection between scientific knowledge and transformation of the external environment, or between science and power. Static balance of the technological relationship between society and nature, without possibilities for change, without the transformed ambition so characteristic of the modern world, was a remarkable feature of eminently rural character of ancient society (Schiavone, 2005: 197-219).

Going to the core of Marx's and Weber's assumptions, Schiavone fundamentally denies them, asserting that slavery was not responsible for the technological delay, disconnection between production and machine, because this goes back to more distant conditions, prior to slavery, despite the massive presence of slaves supplying in part the effects of the mechanic deficit, ensuring reserve of cheap energy and an economy towards the exchange, commercial circulation, urban development. Therefore, the slave labor was not inefficient, nor "irrationally" organized, but it could not promote a capitalist transformation, because it was symmetrical to the aristocratic values which, in turn, they do not cultivate a mechanical and quantitative view of nature. The slave labor and free labor present are displayed as two opposing formalisms: slave labor, based on the status, is defined by the personal relationship of dependence, exerts its strength from the personal domain and prevents the separation between the personality of the laborer and the sale of labor force to the detriment of a total submission; while the free labor, based on the contract, is defined by the exchange between two juridically equal subjects, acting in favor of the capital and the market, allowing a new connection between subjectivity and productive work, something unimaginable in Antiquity (Schiavone, 2005: 197-219). 
Thus, notwithstanding some similar characteristics between the ancient world and the modern one: urban life, trade, division of labor, etc., there is no direct derivation of the ancient world, because the commercial circulation, for example, between these worlds, was intrinsically different, having no more than the possibility to assert some functional symmetries that lead to similarities typological. The modern West was determined through mental and social acquisitions fully alien to the Greco-Roman world, in addition to a long civil reappropriation of labor and the invention of a relationship between dependent labor and personal freedom, as well as the reconquest of a physical dimension of nature, as condition of an alliance between intelligence and productivity. Hence the importance of works as Weber's The Protestant Ethic and the Spirit of Capitalism and "The Accumulation of Capital" of Marx's book The Capital, reflections which very clearly distinguish the characteristics of the modern world, products of economic and mental transformations which do not refer to the ancient world.

\section{The East and the West: A Dichotomy resulting from a Eurocentric View}

The discontinuity between the ancient world and the modern West is a relevant contribution of Marx and Weber to understand the modern world and Antiquity. However, these scholars were also responsible for paradigms that have reinforced the Eurocentric view about the ancient world, arguing that the cultural and political roots of the modern West lie in Classical Antiquity, despite the rupture between the ancient world and the modern one. In this sense, it forged a tradition of thought in which the ancient societies of the East were very different from societies in the Greco-Roman world, marked by the absence of several social, economic, and political traces, existing in the West. One of the main arguments of these differences was the uniqueness of the West, without connection to other Asian societies and previous periods. The Eurocentric tradition that Marx and Weber are defends the paradigm that the Classical Antiquity would have been the founder of aspects related to foreign policy democracy -, culture - literacy and arts - and in the field of social organization, private property.

In the same way that Marx rejected the hypothesis of the English classic economists in relation to the continuities between Classical Antiquity and the modern world, he also allowed himself to be led by the observation of static character in which the Asia would be: an agricultural economy and a servile peasant class, dominated by a despotic power. For these reasons, these people could never reach the capitalism, because the main 
feature of this "Asian singularity", in the words of Goody (2000: 12), is a stagnant oriental form of society.

The unit between the community and the property or behavior in relation to the objective conditions of production as natural existence has its living reality in a "mode of production", which translates as behavior of some individuals in relation to others, or as their determined behavior in relation to the inorganic nature. The concept of mode of production is a joint historically given the productive forces and the relations of production that correspond to them. Many of the misunderstandings and confusions of interpretations about the Marxian concept of mode of production arise from the reading of the Preface to the Contribution to the Critique of Political Economy, written in 1859 and published in the same year, in which Marx refers to the mode of production of Asia in the economic training of society, the old, the feudal and the modern bourgeois, this being the last form antagonistic of the social process of production (Marx, 2008: 48).

The property originally means a human being's relation to his natural conditions of production as belonging to him, as presupposed conditions with its own existence. The human being associated to the natural conditions of production in two ways: (1) as a member of a community which in its original form is a tribal system, and (2) by their behavior in relation to the land, mediated by the community, as its community property and as individual ownership. Therefore, the property means belonging to a community, with subjective-objective existence in it (Marx, 2011: 651-652). The property is an individual's behavior (which reproduces himself) that works (which produces) in relation to the conditions of their production or reproduction as conditions that are his. Thus, the property will have distinct forms, according to the conditions of production, a mode of production determined. The different forms of property in pre-capitalist societies, the purpose of labor is not the creation of value, but the conservation of natural proprietor and his family, as well as the community.

In an oriental form, the property only exists as communal property, the individual member as such is only possessor, the hereditary or not, of a part as a member of the community. There is only a collective community and only private possession, being historically modified very uneven, depending on whether the labor is performed separately by the private possessor or determined by the community or by unity above the community, which is above all these little communities, appearing as the higher proprietor or as the sole proprietor, the despot, the royal proprietor and the royal presupposition of communal property. With 
this, the product surplus belongs to the collectivity, obtained by means of the tribute or in collective labor for the exaltation of the unity, partly of the royal despot, partly of the imagined clan-being, the god, legally determined due to the royal appropriation by labor (Marx, 2011: 628630).

The second form of property is related to the Greco-Roman societies, the land is occupied by the community, the Roman land (Marx primarily dealt to Roman society); a part remains to the community, the other part is divided up and each parcel of land is Roman by being the private property, the domain of a citizen, the quota belonging to him. Membership in the community remains the presupposition for the appropriation of land, but, as a member of the community, the individual is a private proprietor. As the community (State) here is the presupposition of property of land - i.e., the relationship of the laborer subject to the natural presuppositions of labor as belonging to him -, this belonging, however, is mediated by its being as a member of the State (Marx, 2011: 633-636).

According to Marx, the history of classical antiquity is the story of the cities based on the property of the land and on the agriculture, is a just constituent seat of the field population. The field here appears as a territory belonging to the town and the war is the great common task and the community, consisting of families initially, organized as warlike community, this is one of the conditions of its existence as proprietor, concentrated in the city. The communal property - as property of the State, ager publicus - is here separated of private property. In the Asiatic formations, there is a kind of unity regardless of town and country and the cities formed alongside these villages only at exceptionally good points for external trade; or where the head of the state and his satraps exchange their revenue (surplus product) for labor (Marx, 2011: 631-633).

In addition, the Greco-Roman formations are characterized by the preservation of equality among its free self-sustaining farmers and their labor as a condition for the continuity of their property. The acquisition of wealth is not his central object, but self-sustenance, his own reproduction as a member of the community, as proprietor of the parcel of ground, and, in that quality, as a member of the communa, as self-sustaining peasants, whose surplus time just belongs to the communa, the military service.

Both in the West and the East, the property of the land and agriculture constitute the basis of the economic order, however the Asian form remains with more tenacity, resisting more the historic changes because 
of unity between agriculture and manufacture, and the absence of autonomy of the individual in relation to the community. In the West, where there is already a separation between the members of the community as private proprietor themselves as the urban community and proprietors of the urban territory, the conditions are already given in which the individual can "lose" his property, i.e. the double relation which makes him both an equal citizen, a member of the community, and a "proprietor". In the oriental form this "loss" is hardly possible, except by altogether external influences, since the individual member of the community never enters a free relation towards it and in which he could lose his bond (economic objective with the community). He is rooted. On the other hand, it also depends on the association between the combination of manufacture and agriculture, of town (village) and countryside. Among the ancients, especially the Romans, manufacture appears as a corruption (business for freedmen, "clients", aliens) etc. This development of productive labor, which necessarily results from intercourse with aliens and slaves, through the desire to exchange the surplus product etc., dissolves the mode of production on which the community is based (Marx, 2011: 655-656).

In Agrarverhältnisse im Altertum, originally written in 1897, rewritten in the following year and, finally, published in 1908, translated into English in 1909, under the title of The Agrarian Sociology of Ancient Civilizations, after his nervous breakdown, Weber displays an overview of the four great civilizations of the ancient world. Here, Weber bows to the criticism of modernist historians to limit the importance of the oikos in the economy of the ancient world and to divide the Antiquity in distinct socioeconomic and cultural areas, in civilizations, in which each one has gone through specific forms of development. Finally, Weber takes a step beyond the primitivists, by separating the classic polis in the oikos economy, associating the decline of the oikos to the development of polis and, subsequently, to capitalism. The oikos has a prominent role in Greece in the initial stages, in the Near East and, at the end of Antiquity in the Roman Empire. The importance of the oikos is associated to royalty in the West and East, however, interrupted in the West with the emergence of the aristocratic polis and the abolition of royalty. The historicity of these historical stages dissolves the unit concepts elaborated by Bücher, in which the linear view is replaced by a cyclical view, which is different from that of Meyer, who related periods of Antiquity with periods of the Modern Age in a similar manner.

Weber was already using the oikos as an ideal type and sought to realize in his historical studies, the ancient civilizations that were next or far 
from his model. In The Agrarian Sociology of Ancient Civilizations, Weber suggests the development of a military urban particularism of the Greek polis as the main differentiating element of bureaucratic monarchies of the Near East. In contrast with the growth of a royal retinue extremely dependent on the king in the East, in Greece there was a domination of the royal retinues and, consequently, there was the development of an army recruited among small farmers who could provide their own arms. This peculiarity has led to the weakening of royal power and the lack of royal bureaucracies and large states, remarkable trace of the development of the eastern monarchies (Weber, 2013: 157-158).

The insistence on universal categories such as capitalism, bureaucracy, feudalism and even "West" appears in The Agrarian Sociology of Ancient Civilizations by comparison between the Greco-Roman poleis and formations of the Near East. In so far as the politician takes a leading role in the analysis of the economic structures, the capitalism became dominant in the West. The rupture with the kingship in the West opens the way for the emergence of the polis and capitalism, something that does not happen in the East. It is only in the city-states that new forms of political rule, economic interaction or ideological legitimacy develop in clearly distinguished geopolitical entities. Therefore, the polis is an influential causal element which keeps off the Greek and Roman societies of oikos model.

Weber also proposes a series of stages of development for the Near East, whose types - from the royal fortress to authoritarian liturgical states or bureaucratic kingdoms - are forms of political organization in which the state bureaucracy, while represses the capitalism, emphasizes and strengthens the role of the royal oikos, monopoly of the one who holds political, ideological and economic power, and it includes the army, bureaucracy and the temple. Differently from Rodbertus and Bücher, who define oikos as the main institution of Greco-Roman civilization, Weber applies it as predominant in oriental bureaucratic royalties and as an obstacle to the emergence of the polis and development of capitalism and feudalism. The shift in focus is the institutional role of the state - the bureaucratic royalties that determines the course of economic transactions at the expense of market forces.

In some conferences, pronounced in 1909, he criticized the Prussian bureaucracy in terms almost identical to that made in The Agrarian Sociology of Ancient Civilizations to societies of the Ancient Near East and even to the imperial Rome. Britain, the United States and France supplied, at that moment, the comparative positive points. Notwithstanding criticism of the bureaucratic ideal of life, Weber 
preferred the bureaucratization of modern capitalist society to the peace and security of the total bureaucracy promised by socialism (Nafissi, 2005: 122). Therefore, at the time of The Agrarian Sociology of Ancient Civilizations Weber took as comparative parameters the Prussian bureaucracy and socialism and not the modern capitalist societies.

Between 1911-1913, Weber wrote another paper in which he discussed about the ancient world, entitled "Die nichtlegitime herrschaft Typologie der stadte" ("Non-Legitimate Domination: The Typologies of Cities"), published in Wirtschaft und Gesellschaft (Economy and Society). This work has as the main comparative point not only the East and the West, but also ancient and modern capitalism. The line of continuity between The Agrarian Sociology of Ancient Civilizations and "NonLegitimate Domination: The Typologies of Cities" is the study of the foundations of the city associated with development also peculiar to the West. However, in this book, Weber stops to see the ancient societies under a perspective of a historian of Antiquity, going to primarily see them as comparative elements of reference for a better understanding of the peculiarities of modern capitalism, of its emergence and its future. Therefore, we find little developed elements of Weber's Sociology in the first book, as state domination, patriarchy, charisma, rationality and irrationality.

In "Non-Legitimate Domination: The Typologies of Cities", the author emphasizes the role of the political sphere about the type of dominant capitalism in the ancient world. Unlike the rationality of capitalist production, the acquisition opportunities in the ancient world directed to "supply of the state, [...], to the expansion and conquest of slaves, land, taxes and privileges for the acquisition of land and loans on these, beyond trade and supply in the subject cities" (Weber, 2004: 500). Thus, Weber seeks to particularly demonstrate in "Non-Legitimate Domination: The Typologies of Cities" that the form of political domination in which the values (ethos) of a warrior assembly predominated created obstacles to the development of economic activities. This idea is not absent in The Agrarian Sociology of Ancient Civilizations, however, here, Weber seeks to emphasize the leading role of the polis in the formation of a type of capitalism as opposed to the East, as a stage of historical development "advanced", while in "The domination is not legitimate: The typology of cities" the capitalism represents a still embryonic stage in relation to modern capitalism.

Despite to the rejection to Marxism as a political ideology, the influence of Marx in the work of Weber on the Antiquity, rather the ancient economy, is in the theoretical basis of his arguments in the definition of 
the problem of capitalist development. Moreover, seen as a specificity of the West, a justification for the "backwardness" of the East compared to the West, the absence of the development of private property and capitalism in the ancient East is shared by Marx and Weber and, then followed by Polanyi and Finley, with different arguments. This is a dominant perspective in the nineteenth and twentieth centuries, which sought the origins of European and western culture in Greco-Roman societies, however it is currently being argued by scholars, historians and anthropologists, who highlight common aspects and interactions, to the detriment of the peculiarities and insolation of the classical world.

In his study on the ancient civilizations, The Agrarian Sociology of Ancient Civilizations, Weber's dogmatism here arises from his desire to reconcile two assumptions about capitalism and antiquity which are at first sight in contradiction. On the one hand, he wants to oppose the view (supported by Marx amongst others) that capitalism is unique to the modern world. With this propose in mind, Weber begins to model a sufficiently broad definition of capitalism (not based on the labor contract), allowing the inclusion of certain types of activity found in the antiquity and elsewhere. Then he claims some "capitalist activities", such as those involving the exploitation of slaves, because the elsewhere and the money were indispensable there. On the other hand, Weber is also concerned in exploring the difference of the ancient economy from modern capitalism; although it did not follow the same lines as those of Marxist scheme. This explains the qualifications of his initial view (that capitalism existed in the antiquity), as we have seen, at times almost to the opposite where seems to be only a description of a dividing line that the category of capitalism is applicable at all. Thus, Weber's misconception, arises from his desire to overcome the limitations of both the primitivist approach and the modernist one; he wants to reconcile the standpoint of historians as Mommsen and Meyer (emphasizing the role of the capital and the suitability of modern analogies etc.) with those of Rodbertus and Bücher (highlighting the uniqueness of the antiquity and importance of oikos, urban autarchy and rentiership). The result is not entirely satisfactory, and even one might say that the synthesis taken from Weber is sometimes contradictory (Love, 1991: 32).

Therefore, both Marx and Weber attach to Classical Antiquity a "founding" role to Western culture. In the case of Weber, it is by the presence of capitalism and the polis, and Marx, by the presence of private property and democracy. However, this Eurocentric perspective, very existing in the nineteenth century, has been strongly contested in the 
current historiography. ${ }^{4}$ The contacts between the civilizations of the Greco-Roman world and the Ancient Near East with economic and cultural exchanges rights have been increasingly marked by current studies. In fact, the central concern of Marx and Weber from capitalism, its origin and overcoming, in the case of Marx, explains in large part this Eurocentric character of their models.

\section{Conclusion}

In their scientific models Karl Marx and Max Weber are concerned with a conception of which was specific to the modern world, rather capitalism or a type of capitalism. The two authors offered two consistent historical explanations about the origins, development and significance of capitalism. According to Colliot-Thélène (1995: 51-64), Marx concerned with a science of reality deals to real individuals, their action and their material conditions of life. The reality organizes from the categories that orientate the way of research from the beginning. The concepts of productive forces, social relations, political structures and representations give this reality a hierarchical structure, fixed by order of the causal determinations, elements existent in the Weberian sociology that is concerned with the causal connections, linked by practices, structures and forms of representations. In this work, at investigating the reflections of these scholars about the ancient economy and societies, we conclude that the opposition between economic monism and Weberian causal pluralism is not enough to be a so acute disagreement, despite present, "when it takes a common project of understanding the history that has as its center of interest the social activity of men" (Colliot-Thélène, 1995: 64).

In fact, because Marx offers a narrative of historical transformation linked to a political agenda explicitly of the revolution, while Weber was skeptical and even hostile to this agenda, the accentuation of differences between these two authors cannot hide how Weber is debtor for various insights raised by Marx. The institutional differentiation between economics and politics, so dear to Weber, and subsequently to Polanyi, finds affinity with the Marxist idea which it is only possible to extract the surplus of the peasant through an extra-economic coercion beds cost in societies pre-capitalists. In a moment of strong influence of postmodernism, the theories of Marx and Weber are compromised with the explanation of historical processes on a large scale, with the theoretical generalizations with which the explanations are intelligible, and with the

4 See Goody (2008). 
affirmation of its theoretical assumptions, so that they can be subjected to a critical analysis and empirical evaluation. Therefore, even making explicit the limits of the analysis of these two authors, the dialog with these two research programs is still very fruitful for the current historiography, as for example, the work of Schiavone.

\section{Bibliographic References}

BÜCHER, K. Études d'histoire et d'economie politique. Bruxelles; Paris: Henri Lamertin Éditeur; Felix Alcan Éditeur, 1901.

CARDOSO, C. F. S. Marx e Engels: história e economia política. Aspectos gerais e considerações sobre um tema específico, relativo à antiguidade clássica: a circulação de mercadorias. In: CARVALHO, A. G. (Org.) A Economia Antiga: História e Historiografia. Vitória da Conquista: Edições UESB, 2011. p. 13-38.

CARVAlHO, A. G. (Org.) A Economia Antiga: História e Historiografia. Vitória da Conquista: Edições UESB, 2011.

COLLIOT-THÉLÈNE, C. Max Weber e a história. São Paulo: Brasiliense, 1995.

FREUND, J. Sociologia de Max Weber. Forense Universitária: Rio de Janeiro, 1980.

GOODY, J. O Oriente no Ocidente. Algés: Difel, 2000.

O Roubo da História. Como os europeus se apropriaram das ideias e invenções do Oriente. São Paulo: Contexto, 2008.

LOVE. J. R. Antiquity and Capitalism. Max Weber and the sociological foundations of Roman civilization. London; New York: Routledge, 1991.

MARX, K.A ideologia Alemã. Lisbon; São Paulo: Editorial Presença; Martins Fontes, 1965.

. Grundrisse. São Paulo: Boitempo, 2011.

Prefácio à contribuição à crítica da economia política. In:

A contribuição à crítica da economia política. Translated by Florestan Fernandes. 2. ed. São Paulo: Editora Expressão Popular, 2008. p. 45-50.

MATA, S. A fascinação weberiana. Belo Horizonte: Editora Fino Traço, 2013. 
MEYER, E. El historiador y la historia antigua. Estudios sobre la teoría de la Historia y la Historia económica y política de la Antigüedad. México; Buenos Aires: Fondo de cultura económica, 1955.

MORLEY, N. Antiquity and Modernity. Oxford: Wiley- Blackwell. 2009.

NAFISSI, M. Ancient Athens \& Modern Ideology. Value, theory \& evidence in historical sciences. Max Weber, Karl Polanyi \& Moses Finley. London: Institute of classical studies, 2005.

Classe, engaste (embeddedness) e a modernidade da Atenas Antiga. In. CARVALHO, A. G. (Org.) A Economia Antiga: História e Historiografia. Vitória da Conquista: Edições UESB, 2011.

SCHIAVONE, A. Uma história rompida. Roma antiga e o Ocidente moderno. Translated by Fábio Duarte Joly. São Paulo: Edusp, 2005.

TURATTI, M. C. M. Antropologia, economia e marxismo. São Paulo: Alameda, 2011.

WEBER, M. The Agrarian sociology of ancient civilizations. Translated by R. I. Frank. London; New York: Verso, 2013.

Economia e Sociedade: Fundamentos da sociologia compreensiva. Translated by Regis Barbosa and Karen Elsabe Barbosa. 4. ed. Brasília: $\mathrm{UnB}, 2004.2 \mathrm{v}$.

WIENER, J. "Max Weber's Marxism: Theory and Method in 'The agrarian sociology of ancient civilizations'". Theory and Society, v. 11, n. 3, 1982, p. 389-401. 